\title{
Desulfurization, denitrogenation and deoxygenation of shale oil
}

\author{
Zachariah Steven Baird*, Heino Rang†, Vahur Oja
}

Department of Energy Technology, Tallinn University of Technology, Ehitajate tee 5, 19086 Tallinn, Estonia

Received 19.11.2020, accepted 16.05.2021, available online 10.06.2021

\begin{abstract}
Producing valuable transportation fuels from shale oil has long been a goal among the industries concerned, but to meet modern environmental regulations a significant upgrading is required involving removing heteroatoms from it. The quantity of sulfur, nitrogen and oxygen in shale oil is one of the major obstacles to its wider use. Unlike petroleum whose upgrading consists mainly in desulfurization, for shale oils denitrification and deoxygenation are also important. This review compiles and summarizes the extensive research that has been performed on removing sulfur, nitrogen and oxygen from shale oil. By far the most widely investigated method has been hydrotreatment, but the results of work done with other methods are also presented.
\end{abstract}

Keywords: shale oil, desulfurization, denitrification, deoxygenation, refining, fuel.

\section{Introduction}

Shale oil has long been touted as a substitute for conventional petroleum [1]. It is a liquid fuel produced from solid oil shale via a process called pyrolysis $[2,3]$, and it has been estimated that at least 4.7 trillion barrels of oil could be produced from known deposits [4]. However, technical and environmental challenges have largely kept shale oil production from being economically feasible [5]. Nevertheless, shale oil is currently produced industrially in Brazil, China and Estonia [4], and due to the sheer size of the resources, shale oil continually attracts attention, especially in times when oil prices are high.

Transportation fuels have been produced commercially from shale oil in the past, but not in recent history. During the 1920s, 1930s and 1940s motor fuels were commercially produced in Estonia from oil shale [6, 7]. Likewise,

\footnotetext{
* Corresponding author: e-mail zachariah.baird@taltech.ee

(C) 2021 Authors. This is an Open Access article distributed under the terms and conditions of the Creative Commons Attribution-NonCommercial 4.0 International License (http://creativecommons.org/licenses/by-nc/4.0/).
} 
motor fuels were produced in China in the 1940s and 1950s [8]. In Australia during World War II transportation fuels were also produced from shale oil to meet wartime demand [9]. Transportation fuels have been commercially produced in South Africa as well $[10,11]$. However, these fuels would not meet modern environmental regulations because desulfurization, denitrogenation and deoxygenation were only performed to a minor extent, if at all. For this reason, in more recent history shale oil has mostly been used as a lower value product, e.g. fuel oil or boiler fuel $[8,12]$.

To produce transportation fuels from shale oil that meet current environmental standards a significant upgrading is needed to remove the large quantities of sulfur, nitrogen and oxygen usually present in oil [13]. Given the importance of removing these heteroatoms, a lot of research has been done on different methods for doing so, with some early studies dating back as far as 1930 [14-16]. Processes for desulfurization, denitrogenation and deoxygenation of shale oil have also been of interest to shale oil companies as a way to add higher value products to their portfolios. For example, Eesti Energia, a shale oil company, recently carried out extensive analysis and pilot plant testing with the goal of producing Euro V diesel from shale oil [17]. Due to the continual interest in shale oil upgrading, we found it important to compile and summarize the existing research on the subject to aid researchers who will work on this problem in the future. Earlier reviews can be found about the removal of heteroatoms from petroleum and biofuels (see, for example, $[18,19])$, but shale oil has a different composition and will likely require upgrading pathways that are different from those currently used in refineries $[20,21]$. Therefore, here we present what is, to our knowledge, the first thorough review of research on desulfurization, denitrogenation and deoxygenation of shale oil.

\section{Composition of shale oil}

Kerogen, the main organic structure in oil shale [2, 22-24], is usually described as a three-dimensional macromolecular substance [25]. Oil shale is a broad term, and the structure and composition of its kerogen can vary widely between deposits $[26,27]$. The differences between different oil shales, along with differences in the retorting methods used, lead to dissimilarities in the composition and properties between the shale oils produced [28, 29].

Some representative structures have been presented for the kerogens in Kukersite [30], Green River [25, 31, 32] and Rundle [31] oil shales and Guttenberg Member kerogen [30]. Generally, kerogen can be described as consisting of ring structures connected by long straight hydrocarbon chains. Heteroatoms are also distributed throughout the structure. These structural features can often be found in the resulting oil. For example, in Kukersite shale oil a main class of compounds is phenols with straight alkyl side chains [33,34], 
and these structural features can be seen in the representative model of Kukersite kerogen [30]. Due to the structure of kerogen, aromatic compounds are common in many shale oils. Aromatic compounds can also arise due to secondary reactions that occur during pyrolysis [35].

As with other unconventional fuels such as biofuels and coal liquids, shale oil usually contains higher amounts of heteroatoms than conventional petroleum. For conventional petroleum crude the elemental composition generally is the following: 82-88 wt $\% \mathrm{C}, 10-16 \mathrm{wt} \% \mathrm{H}, 0-1 \mathrm{wt} \% \mathrm{~N}$ and $0-6 \mathrm{wt} \% \mathrm{~S}$, with very little oxygen, if any [36]. Based on literature data we collected on more than 200 crude shale oil samples, the composition of shale oil is mainly the following: $78-86 \mathrm{wt} \% \mathrm{C}, 7-13 \mathrm{wt} \% \mathrm{H}, 0.1-3 \mathrm{wt} \% \mathrm{~N}$, 0.3-9 wt $\% \mathrm{~S}$ and 0.4-7 wt\% O. Figure 1, Figure 2 and Figure 3 depict histograms showing the distribution of petroleum and crude shale oil samples based on the amount of heteroatoms they contain. From this information it can be seen that shale oil generally contains significantly more heteroatoms than crude oil. Also, note that in petroleum the majority of heteroatomic compounds are sulfur compounds, but in shale oil nitrogen and oxygen are also often present in large quantities. Given the large number of heteroatoms, a significant portion of the compounds in shale oil contain heteroatoms. In Green River shale oil, for instance, $61 \%$ of the compounds contained a heteroatom [37].

The sulfur compounds often found in shale oil include thiophenes, benzothiophenes, dibenzothiophenes, thioesters and thiols [34, 38-42]. Some disulfides may also be present [40]. The main classes of nitrogen compounds are pyridines, pyrroles, quinolones, carbazoles, indoles, acridines and some nitriles [41, 43-45]. Oxygen compounds include phenols, resorcinols, ketones,

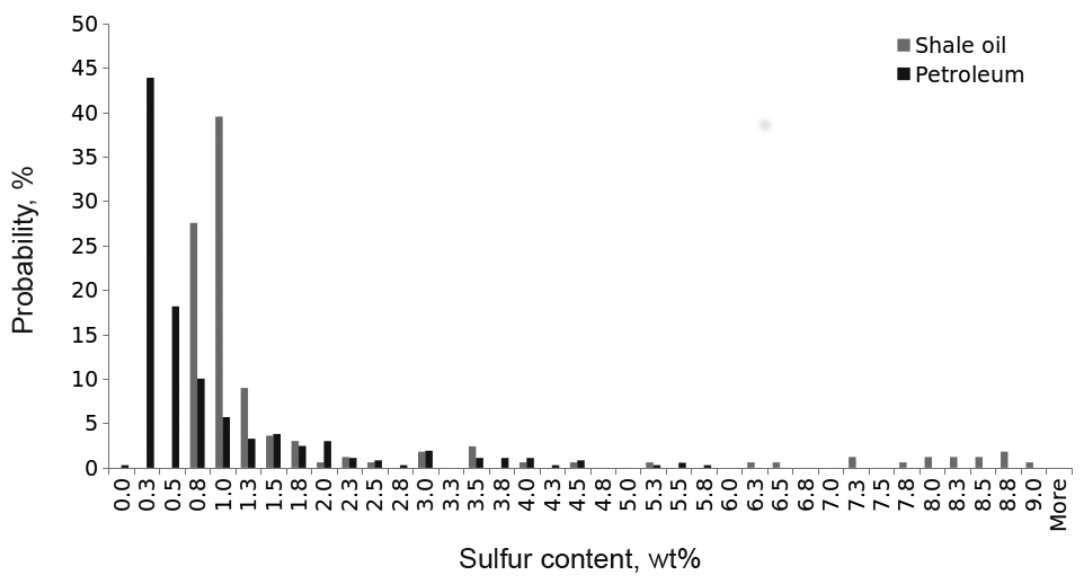

Fig. 1. Distribution of crude shale oil and crude petroleum samples based on sulfur content. Data on crude petroleum are taken from [36]. 


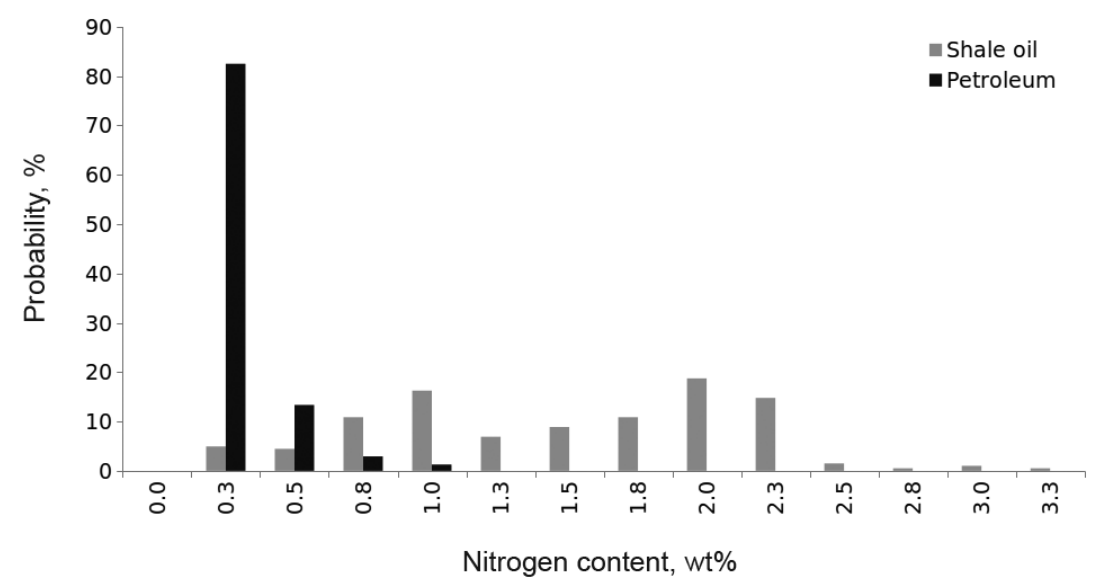

Fig. 2. Distribution of crude shale oil and crude petroleum samples according to nitrogen content. Data on crude petroleum are taken from [36].

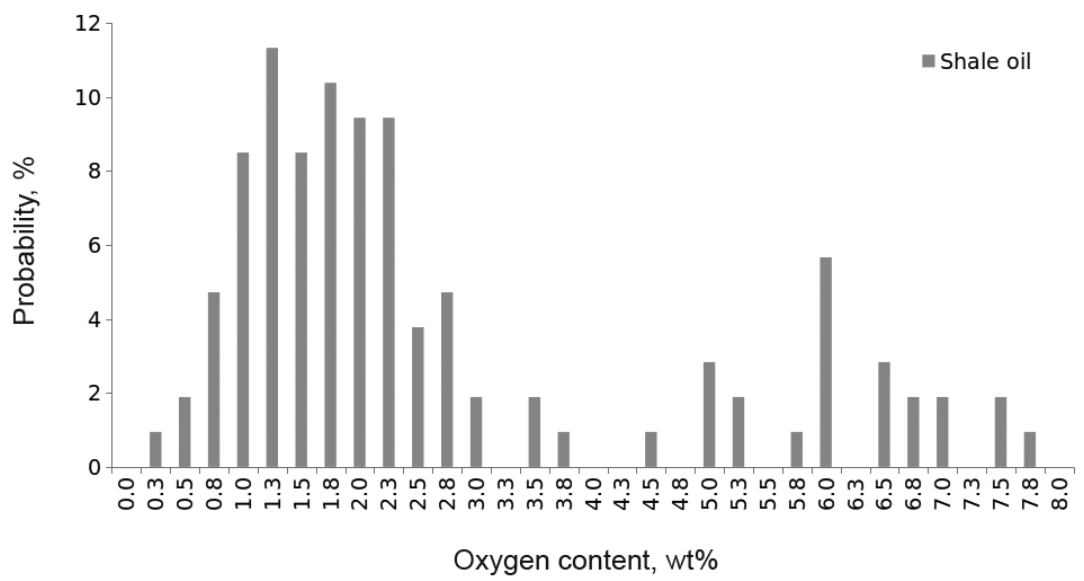

Fig. 3. Distribution of crude shale oil samples based on oxygen content.

organic acids and benzofurans [34, 41, 44]. Hydroxypyridines can also be present [45], and shale oil often contains olefins [34, 37, 41]. As mentioned, the exact composition of a shale oil depends on the composition of the raw oil shale and the retorting/processing methods used, and large differences in composition can be seen between different shale oils.

Another difference between shale oils and conventional petroleum is in the distribution of heteroatoms among different fuel fractions. In conventional 
petroleum there is more sulfur and nitrogen in the higher boiling portions of the crude [36]. Although this trend also generally holds for the nitrogen in shale oils, sulfur and oxygen compounds are often most concentrated in lower boiling fractions [33, 37, 46-55]. Thus, separating out lighter portions of shale oil via distillation may actually increase the concentration of heteroatoms in the distillate.

Because the composition of shale oil is different from that of conventional petroleum, the former generally requires refining pathways that are different from those currently used in petroleum refineries $[13,21]$.

\section{Technologies used for removing heteroatoms from shale oil}

\subsection{Hydrotreatment}

By far the most commonly used technology for removing heteroatoms from shale has been hydrotreatment [1, 14-16, 20, 39, 43, 44, 56-102]. In hydrotreating reactions occur between hydrogen and oil in the presence of a catalyst. Hydrogen reacts with unsaturated carbon bonds and heteroatoms, and the latter can then be removed in the form of a gas $\left(\mathrm{H}_{2} \mathrm{~S}, \mathrm{NH}_{3}\right.$ or $\left.\mathrm{H}_{2} \mathrm{O}\right)$. Generally, the reactions are carried out at high temperatures and pressures, often about 300 to $400{ }^{\circ} \mathrm{C}$ and 10 to $20 \mathrm{MPa}$.

Hydrotreatment generally gives a good quality oil and a high yield. The concentrations of heteroatoms in oil can be reduced to quite low levels, but reaching these low concentrations requires severe hydrotreating conditions that may be quite costly. To make the upgrading process more economical, it has often been suggested that hydrotreatment be combined with other methods (such as coking or extraction) or only be used to the point at which oil can be used as a feedstock for a conventional refinery $[69,83,84]$.

Most studies have been performed using autoclaves or fixed bed reactors. Some processes have employed an ebullated bed reactor, which represents a three-phase fluidized bed reactor $[72-74,79,91]$. A trickle bed reactor has also been used by some researchers $[88,103,104]$. This type of reactor similarly involves three phases, but the solid phase is stationary. A few processes have employed multistage reactors as well [20, 56-58, 86, 92].

A variety of different catalysts, often commercial ones, have been used. On many occasions, the exact composition and properties of the catalyst have not been given. Some common metals used in the catalysts include $\mathrm{Co}, \mathrm{Ni}, \mathrm{W}$ and Mo along with silica and alumina. Early studies also investigated using reduced iron ore [14, 15], and Shamsi [105] studied the catalytic properties of the mineral portion of oil shale.

Several studies have combined coking with hydrotreatment in an attempt to increase process efficiency. In the coking process a fuel is heated until thermal decomposition occurs, which leads to the production of smaller molecules that are recovered as a liquid or gas and a solid carbon residue called coke [106]. 
Note that these studies have used coking as a treatment step, so the coking began with shale oil, not raw oil shale. One advantage of using coking with shale oil is that any solids or metals remain in the residue from the coking process, making it easier to further refine the remaining liquid fuel [84]. In the late 1940s the United States Bureau of Mines constructed a small refinery that used coking (thermal cracking) as the first step [21]. For delayed coking with recycle they reported yields of $40.6 \mathrm{vol} \%$ gasoline and $39.1 \mathrm{vol} \%$ light gas oil. Distillates from the coking unit were further treated by extraction with basic and acidic solutions to remove some of the sulfur and nitrogen compounds. Similar coking experiments were also performed at about the same time by Egloff et al. [10, 107].

Sullivan and Stangeland [82] also investigated using coking as the first step in upgrading shale oil. They reported a $77.9 \%$ yield of $\mathrm{C}_{5}+$ liquid and a coke yield of $18.3 \%$. They then further processed the liquid fuel in a hydrotreating pilot plant. The researchers noted that the coking-hydrotreating process was less costly than other refining processes investigated by them. However, the process was claimed to be "the least energy efficient in the production of transportation fuels".

Shale oil has generally not been upgraded at an industrial scale. Two known exceptions are hydrocracking and hydrogenation performed at the Fushun oil shale plants in China in the 1950s [8] and a commercial scale test performed by the Standard Oil of Ohio in conjunction with the United States Navy in the late 1970s $[90,94]$. Although both were reported to be successful, the upgrading activities were not sustained long term. In China the refinery built for shale oil was instead used for refining petroleum [8]. In the test for the U.S. Navy some problems occurred because $\mathrm{FeS}_{\mathrm{x}}$ deposited in the guard bed used before the hydrotreating unit, which led to the shutting down of the process due to a high pressure drop across the bed. Despite the complications, 73,100 barrels of shale oil was hydrotreated.

\subsection{Catalytic cracking}

Unlike hydrotreating, which largely just saturates carbon bonds and removes heteroatoms, catalytic cracking processes are designed to break carbon bonds in the fuel to form smaller molecules. A few processes used fluid catalytic cracking or hydrocracking as one of the upgrading steps [8, 44, 82-85, 95, 107]. Many studies reviewed for this article seemed to only have the goal of upgrading shale oil enough that it could be used as a feedstock for a conventional refinery. This may explain why catalytic cracking has generally not been used because any need to crack the fuel would be handled in a conventional refinery.

\subsection{Extraction and adsorption}

One way to remove undesired compounds is via extraction or adsorption. Several of the patents on oil shale upgrading processes involve extraction 
steps [70, 71, 80, 81, 108]. After first coking shale oil, Qian and Tian [8] used extraction steps to remove oxygen- and nitrogen-containing compounds from it. Lankford and Morris [21] used a similar process, and Han et al. [109] also removed nitrogen compounds using acidic reagents. Luik et al. [59-65] removed phenolic compounds from shale oil before hydrotreating it. Often a liquid solvent serves as an extracting agent, but some studies have used solid agents, for instance, $\mathrm{CuCl}_{2} \cdot \mathrm{xH}_{2} \mathrm{O}$ or hydrated iron (III) chloride to remove nitrogen compounds [110-112].

Bunger [47] has suggested that extracting some compounds from oil can be economically beneficial if these can be sold as higher value products. At the same time, both Qian and Tian [8] and Lankford and Morris [21] gave this as a reason for extracting heteroatomic compounds. Indeed, in Estonia Viru Keemia Grupp and their predecessors have long recovered water soluble phenols from shale oil to sell or convert to more valuable products [113], and during the Soviet period research was performed to find different ways of using these phenols [114]. However, extraction or adsorption is usually combined with other upgrading methods because on its own it does not reduce the sulfur and nitrogen content to a low enough level, as can be seen from the work by Chi et al. [108].

In addition to the work done on removing sulfur, nitrogen and oxygen, Curtin et al. [69] developed a method to remove arsenic from shale oil. Arsenic can poison catalysts used in hydrotreatment, and it is often desirable to remove it as well. The researchers then used a guard bed filled with the adsorbent to protect the catalyst in the hydrotreater. In the commercial scale test performed at the Standard Oil of Ohio, a guard bed was also used to protect the hydrotreatment unit [90].

\subsection{Hydroretorting}

Shale oil is produced from solid oil shale via pyrolysis in a process called retorting. Some studies and patents have proposed upgrading during the retorting process itself by adding a hydrogen source [16, 115-124]. An advantage of using this method is that almost all of the organic matter in oil shale can be recovered. This is significant because usually in retorting some portion of organic matter forms a solid residue called semi-coke, which remains in oil shale. For some types of oil shale only a relatively low proportion of organic matter can be recovered using traditional retorting methods. However, hydroretorting can afford oil yields similar to those of high yield oil shales [117]. Krichko [118] cited a 96-98\% conversion of the shale organic matter to liquid or gaseous products.

Hydroretorting can result in a shale oil with a lower content of heteroatoms. Though, Krichko [118] showed that a significant amount of heteroatoms can still remain in oil. He stated the sulfur content in the gasoline fraction was $0.6-0.7 \%$. This suggests that hydroretorting may not be as effective as 
hydrotreatment in removing heteroatoms. Changing process conditions, however, may allow better removal of heteroatomic atoms. Abbasian et al. [119], for instance, demonstrated it is possible to capture the $\mathrm{H}_{2} \mathrm{~S}$ formed during hydroretorting directly in the reactor by adding a solid sorbent (limestone or siderite).

It is possible to separate the organic matter in oil shale, called kerogen $[2,22]$, from the mineral material by using a process named floatation $[115,117,125]$. Some of the hydroretorting studies have employed this concentrated kerogen (organic content 80-90\%). Tippin and Rex [117] proposed using this floatation technique in commercial hydroretorting operations.

The majority of hydroretorting studies have used hydrogen gas, but the patents by McCollum and Quick [120, 121] describe employing a watercontaining fluid at supercritical conditions. It appears that the fluid acts as a source of hydrogen for the reactions, and a catalyst is also added to the fluid to promote the conversion process. The patent reveals that the fluid also included organic solvents that could dissolve the shale oil compounds produced during pyrolysis. In addition, the authors stated that their retorting process could remove sulfur compounds and metals from the oil.

Oil shale can be mined and retorted above ground, or it can be retorted within the oil shale formation itself using in situ retorting. Therefore, in situ upgrading techniques have also been proposed in some patents [120-123]. Sometimes the upgrading was performed by pumping hydrogen into the formation during in situ retorting. McCollum and Quick [120, 121] also stated that their method could be used in situ by pumping the fluid directly into the oil shale formation.

It is worth mentioning that changing the retorting conditions, even without adding hydrogen, can also affect the amount of heteroatoms in the resulting shale oil. Elenurm et al. [54] showed this in a pilot-scale solid heat carrier retort, and Oja et al. [55] investigated this in a Fischer assay retort. Although the concentration of heteroatoms generally cannot be reduced to low levels without adding hydrogen, choosing appropriate retorting conditions may make desulfurization, denitrogenation and deoxygenation more efficient.

\section{Hydrotreatment chemistry}

\subsection{Changes in shale oil composition}

A common theme throughout the studies reviewed was that nitrogen compounds are more difficult to remove than sulfur compounds when hydrotreating shale oil. Studies which used milder hydrotreating conditions showed relatively low removal rates, although even at mild conditions most of the sulfur was removed. Landau [13] summarized this by saying that when 
comparing the difficulty of removing different heteroatoms from shale oil $\mathrm{S}<\mathrm{O}<<\mathrm{N}$, and tentatively stated that the concentrations of $\mathrm{S}, \mathrm{O}$ and $\mathrm{N}$ in the hydrotreated products could be reduced to $<0.05 /<0.1 /<0.5 \mathrm{wt} \%$ at "normal" hydrotreating conditions.

One possible reason for an easier removal of sulfur is that shale oil generally does not contain significant quantities of dibenzothiophenes, which are present in larger quantities in crude oil and are more difficult to remove [13, 34, 44, 126]. In addition, Rollmann [126] indicated that when hydrotreating heterocyclic sulfur compounds sulfur will be eliminated in the form of hydrogen sulfide without hydrogenation of the aromatic ring. However, for heterocyclic nitrogen and oxygen compounds hydrogenation seems to be required prior to $\mathrm{C}-\mathrm{N}$ or $\mathrm{C}-\mathrm{O}$ bond scission $[126,127]$. Oxygen compounds have proved to be more easily removed via hydrotreating than nitrogen, with the oxygen content being reduced significantly at even mild processing conditions $[13,43,44]$.

Among nitrogen compounds those contained in ring structures, such as pyrrole, carbazole and pyridine derivatives, are generally the most difficult to remove $[13,128]$. Holmes and Thompson [45] indicated that the most difficult compounds to remove are hindered pyrroles and alkylpyridines. Souza et al. [44] also showed that pyridines, quinolines, indoles and carbazoles still remained in large quantities in the hydrotreated oil. Experiments by Chen et al. [77] demonstrated that most compounds after hydrotreatment contained one nitrogen atom and double bond equivalents of 4 to 10. The basic compounds identified were pyridine derivatives. Harvey et al. [43] also stated that pyrroles were less reactive, at the same time, they reported that pyridines were removed to a significant extent. For further information about the removal of heteroatoms from fuels the reader is referred to excellent reviews by Girgis and Gates [129] and Landau [13].

Hydrogenation of double bonds and aromatic rings is another set of chemical reactions that occur when hydrotreating shale oil. The $\mathrm{H} / \mathrm{C}$ ratio of the fuel increases. Double bonds are saturated fairly rapidly [44]. With aromatic compounds, Afonso et al. [91] determined that the major reactions are partial hydrogenation of aromatic rings and cracking of alkyl side chains. Some studies have also shown that the concentrations of some aromatic compounds can actually increase during hydrotreating [43, 44, 89]. Harvey et al. [43] performed hydrotreatment in different reactors and with different catalysts, and their results indicate that the reactions occurring with aromatic compounds during hydrotreatment can vary significantly depending on the catalyst and processing conditions.

For hydroretorting processes the findings of Burnham and Happe [35] are significant. During pyrolysis/retorting a secondary process that occurs is the conversion of aliphatic hydrocarbons to aromatic hydrocarbons. The researchers found hydrogen to inhibit this process. Therefore, hydroretorting has the potential to produce a shale oil with lower aromaticity. 


\subsection{Notes about catalysts}

Although we do not attempt to thoroughly analyze and compare the different catalysts used (which could be the subject of a separate review), a few findings about these substances are worth mentioning.

The high concentrations of nitrogen in many shale oils can deactivate some catalysts, such as those in fluid catalytic cracking units, and so it may be important to select a catalyst that is not deactivated by nitrogen and sulfur. The H-Oil process carried out in an ebullated bed reactor used such a catalyst [74]. Arsenic, which is present in higher concentrations in many shale oils, can also deactivate catalysts, and its removal may be necessary [69].

Shamsi [105] investigated the catalytic activity of oil shale minerals in hydrodesulfurization reactions by introducing thiophene into a reactor containing the minerals. He showed that almost all the oil shale minerals were catalytically active to some extent, and for some of the minerals more than $50 \%$ of the thiophene was converted at higher temperatures. Therefore, the oil shale minerals present during the retorting process likely have an effect on the composition of the shale oil produced, and this was also shown by Elenurm et al. [54] and Oja et al. [55].

The effectiveness of different catalysts was compared by Benson [130], and of the 12 catalysts studied, the HF-activated Co molybdate gave the best results. Other studies have also shown that increasing the acidity of the catalyst by adding halogens improves their ability to remove nitrogen [13]. For a more detailed discussion of the catalysts used in hydrotreating shale oil the reader is referred to the review by Landau [13].

\section{Conclusions}

It seems likely that hydrotreatment is necessary to reduce the concentrations of heteroatoms in shale oil to acceptable levels. However, using other upgrading methods in addition to hydrotreating may help to improve a refinery's economic performance, for instance, by reducing the cost of the hydrotreatment step. It has been stated that it is economically more beneficial to upgrade fuel only to the point that it could be used as a conventional refinery feed stock.

The review also reveals that nitrogen, especially those contained in ring structures, is the most difficult heteroatom to remove from the fuel during hydrotreatment.

\section{Acknowledgement}

This article is published in memory of Senior Researcher Heino Rang, a talented researcher and memorable colleague, who compiled the initial version of the article while working at the Department of Chemical Engineering, Tallinn University of Technology. 
The work received financial support from the Estonian Science Foundation, under Grant 5018.

\section{REFERENCES}

1. Smith, W. M., Lanum, T. C., Phillips, G. E. Hydrogenation of shale oil. Ind. Eng. Chem., 1952, 44, 586-589.

2. Lee, S. Oil Shale Technology. CRC Press, 1990.

3. Oja, V., Suuberg, E. M. Oil Shale Processing, Chemistry and Technology. In: Encyclopedia of Sustainable Science and Technology (Meyers, R. A., ed.). Springer-Verlag, New York, 2012, 7457-7491.

4. World Energy Council. World Energy Resources 2013 Survey. World Energy Council, London, 2013.

5. Bartis, J. T., LaTourrette, T., Dixon, L., Peterson, D. J., Cecchine, G. Oil Shale Development in the United States: Prospects and Policy Issues. Rand Corporation, 2005.

6. Oja, V. A breaf overview of motor fuels from shale oil of Kukersite. Oil Shale, 2006, 23(2), 160-163.

7. Luts, K. The Estonian Oil Shale Kukersite, its Chemistry, Technology and Analysis (Der estländische Brennschiefer-Kukersit, seine Chemie, Tehnologie und Analyse). K. Mattiesens Buchdruckerei Ant.-Ges., Tartu, Estonia, 1934.

8. Qian, H. Y., Tian, H. Y. A new scheme for upgrading Fushum shale oil. In: Proceedings of the International Conference on Oil Shale and Shale Oil, Beijing, China, 1988, 486-492.

9. Mapstone, G. E. Wartime shale oil production at Marangaroo, N.S.W. In: Proceedings of the Second Oil Shale and Cannel Coal Conference, Glasgow, 1950. The Institute of Petroleum, London, WI, USA, 1951, 489-499.

10. Egloff, G., Walter, J. F., Grote, H. W., Davis, R. F. Refining Australian and South African torbanite oils. In: Proceedings of the Second Oil Shale and Cannel Coal Conference, Glasgow, 1950. The Institute of Petroleum, London, WI, USA, 1951, 605-620.

11. Robertson, R. E. The refining of South African torbanite crude oil. In: Proceedings of the Second Oil Shale and Cannel Coal Conference, Glasgow, 1950. The Institute of Petroleum, London, WI, USA, 1951, 571-583.

12. Shale oil-Eesti Energia. n.d. (in Estonian). http://www.energia.ee/ari/ toostuslahendused/polevkivioli

13. Landau, M. V. Deep hydrotreating of middle distillates from crude and shale oils. Catal. Today, 1997, 36(4), 393-429.

14. Hüsse, J. Hydration and desulfurization of Estonian shale oil. Tehnika Ajakiri, 1930, 11, 162-165 (in Estonian).

15. Koern, T., Removal of sulfur from shale oil. Tehnika Ajakiri, 1930, 11, 166-168 (in Estonian).

16. Kogerman, P. N., Kopvillem, J. Hydrogenation of Estonian oil shale and shale oil. Journal of the Institution of Petroleum Technologists, 1932, 18(108), 833-845. 
17. Low, G., Egelberg, R., Alkilde, O. Upgrading of Estonian shale oil to high quality Euro v diesel. International Oil Shale Symposium, Tallinn, Estonia, June 10-13, 2013, 28.

18. Rang, H., Kann, J., Oja, V. Advances in desulfurization research of liquid fuel. Oil Shale, 2006, 23(2), 164-176.

19. Srivastava, V. C. An evaluation of desulfurization technologies for sulfur removal from liquid fuels. RSC Adv., 2012, 2, 759-783.

20. Landau, M. V., Herskowitz, M., Givony, D., Laichter, S. Process and Catalysts for the Production of Motor Fuels from Shale Oils. WO1997019150 A1, 1997.

21. Lankford, J. D., Morris, J. Refining of Colorado shale oil. A review of work by the Bureau of Mines, U.S. Department of the Interior. In: Proceedings of the Second Oil Shale and Cannel Coal Conference, Glasgow, 1950. The Institute of Petroleum, London, WI, USA, 1951, 500-532.

22. Lille, Ü., Heinmaa, I., Pehk, T. Molecular model of Estonian kukersite kerogen evaluated by ${ }^{13} \mathrm{C}$ MAS NMR spectra. Fuel, 2003, 82(7), 799-804.

23. Hruljova, J., Oja, V. Application of DSC to study the promoting effect of a small amount of high donor number solvent on the solvent swelling of kerogen with non-covalent cross-links in non-polar solvents. Fuel, 2015, 147, 230-235.

24. Hruljova, J., Savest, N., Oja, V., Suuberg, E. M. Kukersite oil shale kerogen solvent swelling in binary mixtures. Fuel, 2013, 105, 77-82.

25. Schmidt-Collerus, J. J., Prien, C. H. Investigation of the hydrocarbon structure of kerogen from oil shale of the Green River Formation. Am. Chem. Soc., Div. Fuel Chem., Prepr., 1974, 19(2), 100-108.

26. Robinson, W. E. Kerogen of the Green River Formation. In: Organic Geochemistry (Eglinton, G., Murphy, M. T. J., eds.). Springer Berlin Heidelberg, 1969, 619-637.

27. Urov, K., Sumberg, A. Characteristics of oil shales and shale-like rocks of known deposits and outcrops: monograph. Oil Shale, 1999, 16(3 SPECIAL). Estonian Acad. Publ., Tallinn, 1999.

28. Guo, S. H. The chemistry of shale oil and its refining. In: Coal, Oil Shale Natural Bitumen, Heavy Oil and Peat - Vol. II. Publishers Company Limited, 2009, 94-106.

29. Järvik, O., Oja, V. Molecular weight distributions and average molecular weights of pyrolysis oils from oil shales: Literature data and measurements by SEC and ASAP MS for oils from four different deposits. Energy Fuels, 2017, 31(1), 328-339.

30. Blokker, P., van Bergen, P., Pancost, R., Collinson, M. E., de Leeuw, J. W., Damste, J. S. S. The chemical structure of Gloeocapsomorpha prisca microfossils: implications for their origin. Geochim. Cosmochim. Acta, 2001, 65(6), 885-900.

31. Siskin, M., $\quad$ Scouten, C. G., $\quad$ Rose, K. D., $\quad$ Aczel, T., $\quad$ Colgrove, S. G., Pabst, Jr., R. E. Detailed structural characterization of the organic material in Rundle Ramsay Crossing and Green River oil shales. In: Composition, Geochemistry and Conversion of Oil Shales (Snape, C., ed.). Springer Netherlands, 1995, 143-158.

32. Orendt, A. M., Pimienta, I. S. O., Badu, S. R., Solum, M. S., Pugmire, R. J., Facelli, J. C., Locke, D. R., Chapman, K. W., Chupas, P. J., Winans, R. E. 
Three-dimensional structure of the Siskin Green River oil shale kerogen model: A comparison between calculated and observed properties. Energy Fuels, 2013, 27(2), 702-710.

33. Baird, Z. S., Oja, V., Järvik, O. Distribution of hydroxyl groups in Kukersite shale oil: Quantitative determination using Fourier transform infrared (FT-IR) spectroscopy. Appl. Spectrosc., 2015, 69(5), 555-562.

34. Derenne, S., Largeau, C., Casadevall, E., Sinninghe Damsté, J. S., Tegelaar, E. W., de Leeuw, J. W. Characterization of Estonian Kukersite by spectroscopy and pyrolysis: Evidence for abundant alkyl phenolic moieties in an Ordovician, marine, type II/I kerogen. Org. Geochem., 1990, 16(4-6), 873-888.

35. Burnham, A. K., Happe, J. A. On the mechanism of kerogen pyrolysis. Fuel, 1984, 63(10), 1353-1356.

36. Speight, J. G. Crude Oil Assay Database. 2015.

37. Cady, W. E., Seelig, H. S. Composition of shale oil. Ind. Eng. Chem., 1952, 44(11), 2636-2641.

38. Andersson, J. T., Schmid, B. Polycyclic aromatic sulfur heterocycles IV. Determination of polycyclic aromatic compounds in a shale oil with the atomic emission detector. J. Chromatogr. A, 1995, 693(2), 325-338.

39. Zehua, Z., Kuangzong, Q., Tingfen, W., Yajie, Z. Preliminary study of hydrotreating of a high sulfur content shale. In: Proceedings of the International Conference on Oil Shale and Shale Oil, Beijing, China, 1988, 451-460.

40. Zelenin, N. I., Fainberg, V. S., Chernysheva, K. B. The Chemistry and Technology of Shale Oil. Chemistry Publishing House, Leningrad, 1968 (in Russian).

41. Dijkmans, T., Djokic, M. R., Van Geem, K. M., Marin, G. B. Comprehensive compositional analysis of sulfur and nitrogen containing compounds in shale oil using GC $\times$ GC - FID/SCD/NCD/TOF-MS. Fuel, 2015, 140, 398-406.

42. Al-Harahsheh, A., Al-Otoom, A. Y., Shawabkeh, R. A. Sulfur distribution in the oil fractions obtained by thermal cracking of Jordanian El-Lajjun oil shale. Energy, 2005, 30(15), 2784-2795.

43. Harvey, T. G., Matheson, T. W., Pratt, K. C., Stanborough, M. S. Catalyst performance in continuous hydrotreating of Rundle shale oil. Ind. Eng. Chem. Proc. Des. Dev., 1986, 25(2), 521-527.

44. Souza, G. L. M., Afonso, J. C., Schmal, M., Cardoso, J. N. Mild hydrocracking of an unstable feedstock in a three-phase fluidized-bed reactor: behavior of the process and of the chemical compounds. Ind. Eng. Chem. Res., 1992, 31, 2127-2133.

45. Holmes, S. A., Thompson, L. F. Nitrogen compound distributions in hydrotreated shale oil products from commercial-scale refining. Fuel, 1983, 62(6), 709-717.

46. Marecaux, P. P. Experiments on the integrated valorization of Severac shale oil. In: Proceedings of the Second Oil Shale and Cannel Coal Conference, Glasgow, 1950, Institute of Petroleum, London, WI, USA, 1951, 673-689 (in French).

47. Bunger, J. W. Shale Oil Value Enhancement Research. James W. Bunger and Associates, Inc., Salt Lake City, UT, USA, 2007.

48. Miknis, F. P., Robertson, R. E. Characterization of Doe Reference Oil Shales: Mahogany Zone, Parachute Creek Member, Green River Formation Oil Shale, 
and Clegg Creek Member, New Albany Shale. Western Research Inst., Laramie, WY (USA), 1987.

49. Lovell, P. F. Production of Utah Shale oils by the Paraho DH and Union 'B' retorting processes. In: Eleventh Oil Shale Symposium Proceedings (Gary, J. H., ed.). Colorado School of Mines Press, Golden, Colorado, 1978, 184-192.

50. Miknis, F. P. Characterization of DOE Reference Oil Shale: Tipton Member, Green River Formation Oil Shale from Wyoming. Western Research Institute, Laramie, WY, USA, 1988.

51. Hill, G. R., Dougan, P. The characteristics of a low temperature in situ shale oil. 96th Annual AIME Meeting, Los Angeles, Calif., Feb. 19-23, 1967.

52. Dinneen, G. U., Allbright, C. S., Ball, J. S. Comparison of Brazilian and Colorado shale oils. Ind. Eng. Chem. Chem. Eng. Data Series, 1957, 2(1), 91-95.

53. Mapstone, G. E. Some properties of crude shale oil and naphtha with a note on carbon disulfide in shale naphta. In: Proceedings of the Second Oil Shale and Cannel Coal Conference, Glasgow, 1950. The Institute of Petroleum, London, WI, USA, 1951, 662-672.

54. Elenurm, A., Oja, V., Tali, E., Tearo, E., Yanchilin, A. Thermal processing of Dictyonema Argillite and Kukersite oil shale: transformation and distribution of sulfur compounds in pilot-scale Galoter process. Oil Shale, 2008, 25(3), 328-334.

55. Oja, V., Elenurm, A., Rohtla, I., Tali, E., Tearo, E., Yanchilin, A. Comparison of oil shales from different deposits: Oil shale pyrolysis and co-pyrolysis with ash. Oil Shale, 2007, 24(2), 101-108.

56. Landau, M. V., Herskowitz, M., Givoni, D., Laichter, S., Yitzhaki, D. Mediumseverity hydrotreating and hydrocracking of Israeli shale oil. 1. Novel catalyst systems. Fuel, 1996, 75(7), 858-866.

57. Landau, M. V., Herskowitz, M., Givoni, D., Laichter, S., Yitzhaki, D. Medium severity hydrotreating and hydrocracking of Israeli shale oil - II. Testing of novel catalyst systems in a trickle bed reactor. Fuel, 1998, 77(1-2), 3-13.

58. Landau, M. V., Herskowitz, M., Givoni, D., Laichter, S., Yitzhaki, D. Medium severity hydrotreating and hydrocracking of Israeli shale oil: III. Hydrocracking of hydrotreated shale oil and its atmospheric residue for full conversion to motor fuels. Fuel 1998, 77(14), 1589-1597.

59. Luik, H., Lindaru, E., Vink, N., Maripuu, L. Upgrading of Estonian shale oil distillation fractions. 1. Hydrogenation of the "diesel fraction". Oil Shale, 1999, 16(2), 141-148.

60. Luik, H., Vink, N., Lindaru, E., Maripuu, L. Upgrading of Estonian shale oil distillation fractions. 2. The effect of time and hydrogen pressure on the yield and composition of "diesel fraction" hydrogenation products. Oil Shale, 1999, 16(3), 249-256.

61. Luik, H., Maripuu, L., Vink, N., Lindaru, E. Upgrading of Estonian shale oil distillation fractions. 3. Hydrogenation of light mazute. Oil Shale, 1999, 16(4), 331-336.

62. Luik, H., Maripuu, L., Vink, N., Lindaru, E. Upgrading of Estonian shale oil distillation fractions. 4 . The effect of time and hydrogen pressure on the yield 
and composition of light mazute hydrogenation products. Oil Shale, 1999, 16(4), 337-342.

63. Luik, H., Vink, N., Lindaru, E., Maripuu, L. Upgrading of Estonian shale oil distillation fractions. 5. Hydrogenation of heavy mazute. Oil Shale, 2000, 17(1), 25-30.

64. Luik, H., Vink, N., Maripuu, L., Lindaru, E. Upgrading of Estonian shale oil distillation fractions. 6. The effect of time and temperature on the yield and composition of heavy mazute hydrogenation products. Oil Shale, 2000, 17(1), $31-36$.

65. Luik, H., Luik, L., Johannes, I., Tiikma, L., Vink, N., Palu, V., Bitjukov, M., Tamvelius, H., Krasulina, J., Kruusement, K., Nechaev, I. Upgrading of Estonian shale oil heavy residuum bituminous fraction by catalytic hydroconversion. Fuel Process. Technol., 2014, 124, 115-122.

66. Harvey, T. G., Matheson, T. W., Pratt, K. C., Stanborough, M. S. Studies of the batch hydrotreatment of Rundle shale oil. Fuel, 1985, 64(7), 925-930.

67. Benyamna, A., Bennouna, C., Moreau, C., Geneste, P. Upgrading of distillate fractions of Timahdit Moroccan shale oil over a sulphided $\mathrm{NiO}-\mathrm{MoO}_{3} \gamma-\mathrm{Al}_{2} \mathrm{O}_{3}$ catalyst. Fuel, 1991, 70(7), 845-848.

68. Yoshida, R., Miyazawa, M., Yoshida, T., Narita, H., Maekawa, Y. Chemical structure changes in Condor shale oil and catalytic activities during catalytic hydrotreatment. Fuel, 1996, 75(1), 99-102.

69. Curtin, D. J., Dearth, J. D., Everett, G. L., Grosboll, M. P., Myers, G. A. Arsenic and nitrogen removal during shale oil upgrading. Am. Chem. Soc., Div. Fuel Chem., Prepr., 1978, 23(4), 18-29.

70. Che, S. C., Madgavkar, A. Upgrading Shale Oil by a Combination Process. US4623444 A, 1986.

71. Madgavkar, A. Upgrading Shale Oil by a Combination Process. US4605489 A, 1986.

72. Kunesh, J. G. Hydrocracking and Hydrotreating Shale Oil in Multiple Catalytic Reactors. US4344840 A, 1982.

73. Hayashi, M., Kohno, F., Masuda, T., Shinoda, N., Shimada, T., Kaneko, M., Fujita, H., Ohmoto, S. Upgrading of shale oil by ebullated-bed reactor. In: Proceedings of the International Conference on Oil Shale and Shale Oil, Beijing, China, 1988, 478-485.

74. Hellwig, K. C., Feigelman, S., Alpert, S. B. Shale oil developments: Upgrading feeds by the H-Oil process. Chem. Eng. Prog., 1966, 62, 51-54.

75. Yu, H., Li, S., Jin, G. Catalytic hydrotreating of the diesel distillate from Fushun shale oil for the production of clean fuel. Energy Fuels, 2010, 24(8), 4419-4424.

76. Yu, H., Li, S., Jin, G. Hydrodesulfurization and hydrodenitrogenation of diesel distillate from Fushun shale oil. Oil Shale, 2010, 27(2), 126-134.

77. Chen, X., Shen, B., Sun, J., Wang, C., Shan, H., Yang, C., Li, C. Characterization and comparison of nitrogen compounds in hydrotreated and untreated shale oil by electrospray ionization (ESI) Fourier Transform Ion Cyclotron Resonance Mass Spectrometry (FT-ICR MS). Energy Fuels, 2012, 26(3), 1707-1714. 
78. Chishti, H. M., Williams, P. T. Aromatic and hetero-aromatic compositional changes during catalytic hydrotreatment of shale oil. Fuel, 1999, 78(15), 1805-1815.

79. Chervenak, M. C., Johnson, C. A., Schuman, S. C. H-oil process treats wide range of oils. Petrol. Refiner, 1960, 39(10), 151-156.

80. Johnson, C. A., Ward, C., Moore, H. F., Hettinger, Jr. W. Combination Process for Upgrading Oil Products of Coal, Shale Oil and Crude Oil to Produce Jet Fuels, Diesel Fuels and Gasoline. US4409092 A, 1983.

81. Taylor, J. L., Hensley, A. L., Forgac, J. M., Tatterson, D. F. Oil Stabilization. US5059303 A, 1991.

82. Sullivan, R. F., Stangeland, B. E. Catalytic hydroprocessing of shale oil to produce distillate fuels. 174th Natl. Am. Chem. Soc. Symp., Chicago, 28 Aug. 2 Sep., IL, USA, 1977.

83. Sullivan, R. F., Stangeland, B. E. Catalytic hydroprocessing of shale oil to produce distillate fuels. In: Refining of Synthetic Crudes, Adv. Chem., 179, American Chemical Society, 1979, 25-51.

84. Sullivan, R. F., Stangeland, B. E. Converting Green River shale oil to transportation fuels. In: 11th Oil Shale Symposium, Colorado School of Mines, 1978, $120-134$.

85. Gorring, R. L., Smith, R. L. Upgrading Shale Oil. US4153540 A, 1979.

86. Thompson, L. F., Holmes, S. A. Effect of multistage hydroprocessing on aromatic and nitrogen compositions of shale oil. Fuel, 1985, 64(1), 9-14.

87. Zingarelli, J. A., Muradian, A., Stephenson, L. Upgrading of Stuart shale oil. Fuel, 1988, 67(10), 1408-1410.

88. Su, Z. S., Liu, P., Cai, L., Zhao, G. F. Hydrotreating of Fushun shale oil. Contemporary Chemical Industry, 2008, 37(3), 246-248 (in Chinese).

89. Williams, P. T., Chishti, H. M. Reaction of nitrogen and sulphur compounds during catalytic hydrotreatment of shale oil. Fuel, 2001, 80(7), 957-963.

90. Wasilk, N. J., Robinson, E. T. Commercial-scale refining of Paraho crude shale oil into military specification fuels. In: Oil Shale, Tar Sands, and Related Materials, ACS Sym. Ser., 163, 1981, 223-235.

91. Afonso, J. C., Schmal, M., Cardoso, J. N., Frety, R. Hydrotreatment of Irati shale oil: behavior of the aromatic fraction. Ind. Eng. Chem. Res., 1991, 30(9), 2133-2137.

92. Bludis, J. A., Lyzinski, D., McKinney, J. D., Sebulsky, R. T., Stauffer, H. C. Hydrodenitrogenation of Shale Oil Using Two Catalysts in Series Reactors. US4022682 A, 1977.

93. Lovell, P. F., Fryback, M. G., Reif, H. E., Schwedock, J. P. Maximize shale oil gasoline. Hydrocarb. Process., 1981, 60(5), 125-130.

94. Robinson, E. T. Refining of Paraho shale oil into military specification fuels. In: 108th AIME Annual Meething, New Orleans, Louisiana, 1979.

95. Hoog, H., Koome, J., Weeda, K. A. Hydrofining and cracking-hydrofining of Colorado shale oil. In: Proceedings of the Second Oil Shale and Cannel Coal Conference, Glasgow, 1950. The Institute of Petroleum, London, WI, USA, 1951, 562-570. 
96. Laine, J., Trimm, D. L. Conversion of heavy oils into more desirable feedstocks. J. Chem. Technol. Biot., 1982, 32(7-12), 813-833.

97. Cawley, C. M. The properties of "diesel" oils prepared from low-temperature tar, cannel tar, and Kimmeridge shale tar. Fuel, 1944, 23, 19-22.

98. Cawley, C. M., Kingman, F. E. T. Hydrogenation of Kimmeridge shale tar. Fuel, 1944, 23, 4-8.

99. MacDougall, D., Cawley, C. M. Recovery and treatment of oil from shale from the Kimmeridge area, Dorset, England. In: Proceedings of the Second Oil Shale and Cannel Coal Conference, Glasgow, 1950. The Institute of Petroleum, London, WI, USA, 1951, 440-448.

100. Reed, H., Berg, C., Multer, H. Retorting and refining of shale oil, Union Oil Co. of California. In: Colorado Mining Association Conference, Denver, Colorado, 1949.

101. Enkhjargal, G., Enkhsaruul, B., Monkhoobor, D., Narangerel, J., Yoshikazu, S. Characterization and hydrotreatment of shale oils of Mongolian oil shales. Oil Shale, 2018, 35(2), 168-182.

102. Aljariri Alhesan, J. S., $\quad$ Marshall, M., Jackson, W. R., $\quad$ Cassidy, P. J., Chaffee, A. L. Catalytic hydropyrolysis of El-Lajjun and Julia Creek shale oils using flow-through and sealed autoclaves. J. Anal. Appl. Pyrol., 2019, 143, 104682.

103. Bej, S. K., Dalai, A. K., Adjaye, J. Kinetics of hydrodesulfurization of heavy gas oil derived from oil-sands bitumen. Petrol. Sci. Technol., 2002, 20(7-8), 867-877.

104. Tang, X., Li, S., Yue, C., He, J., Hou, J. Lumping kinetics of hydrodesulfurization and hydrodenitrogenation of the middle distillate from Chinese shale oil. Oil Shale, 2013, 30(4), 517-535.

105. Shamsi, A. Study of eastern and western oil shale mineral activity for hydrodesulfurization reactions. Ind. Eng. Chem. Res., 1990, 29(7), 1466-1470.

106. U.S. Energy Information Administration (EIA). Today in Energy. Coking is a refinery process that produces $19 \%$ of finished petroleum product exports, January 28, 2013. https://www.eia.gov/todayinenergy/detail.php?id=9731

107. Egloff, G., Walter, J. F., Grote, H. W., Davis, R. F. Cracking Colorado shale oils. In: Proceedings of the Second Oil Shale and Cannel Coal Conference, Glasgow, 1950. The Institute of Petroleum, London, WI, USA, 1951, 533-561.

108. Chi, Y., Li, S., Li, X. Study on shale oil diesel refining. Oil Shale, 2005, 22(3), 359-366.

109. Han, D. Y., Li, G. X., Cao, Z. B., Zhai, X. Y., Yuan, M. M. A Study on the denitrogenation of Fushun shale oil. Energ. Source. Part A, 2013, 35(7), 622-628.

110. Choi, H. W., Dines, M. B. Selective removal of nitrogen compounds from shale oil. Fuel, 1985, 64(1), 4-8.

111. Narangerel, J., Sugimoto, Y. Removal of nitrogen compounds before deep hydrotreatment of synthetic crude oils. J. Jpn. Petrol. Inst., 2008, 51(3), 165-173.

112. Rayner-Canham, G. W., Dickerhoof, D. W. Elucidation of the iron chlorideclay system for removal of nitrogen-containing compounds from petroleum and shale-oil distillates. Fuel, 1984, 63(10), 1472-1474. 
113. VKG. Phenols and Phenol Products. n.d. http://www.vkg.ee/eng/products-andservices/vkg-oil-as/phenols-and-phenol-products

114. Zelenin, N. I., Vassiliev, M. L. Oil shale phenols and ways of their utilization. In: United Nations Symposium on the Development and Utilization of Oil Shale Resources, section 111, Tallinn, August 26 - September 4, 1968, Estonia, 1968.

115. Maloletnev, A. S., Naumov, K. I., Shvedov, I. M., Mazneva, O. A. Shale hydrogenation. Solid Fuel Chem+., 2011, 45, 316-321.

116. Klesment, I., Nappa, L., Vink, N. Results of low-temperature destructive hydrogenation of Estonian kukersite kerogen concentrate. Khimiya Tverdogo Topliva, 1979, 33-39 (in Russian).

117. Tippin, R. B., Rex, R. C. Combined beneficiation and hydroretorting of oil shale. In: Symposium on Chemistry and Processing Supercritical Fluids, 1985, San Francisco, 237-246.

118. Krichko, A. Hydrogenation of oil shale and polymers. Oil Shale, 2000, 17(3), 271-285.

119. Abbasian, J., Rue, D. M., Lau, F. S. In-bed sulphur capture during pressurized fluidized-bed hydroretorting of Eastern oil shales. Fuel, 1991, 70(11), 1342-1346.

120. McCollum, J. D., Quick, L. M. Process for Recovering and Upgrading Hydrocarbons from Oil Shale and Tar Sands. US3948755 A, 1976.

121. McCollum, J. D., Quick, L. M. Process for Recovering and Upgrading Hydrocarbons from Oil Shale. US4151068 A, 1979.

122. Slater, W. L. Recovery of Oil from Oil Shale by Underground Hydrogenation. US3084919 A, 1963.

123. Forgac, J. M., Hoekstra, G. R. Pulsed in Situ Retorting in an Array of Oil Shale Retorts. US4552214 A, 1985.

124. Krasulina, J. Catalytic Hydrogenation of Liquids from Estonian Kukersite Oil Shale: Upgrading of liquid products from Estonian kukersite oil shale by catalytic hydrogenation. TUT Press, Tallinn, 2015.

125. Rembashevskii, A. G., Proskuryakov, V. A. Za Ekonomiyu Topliva, 1951, (12), 14.

126. Rollmann, L. D. Catalytic hydrogenation of model nitrogen, sulfur, and oxygen compounds. J. Catal., 1977, 46(3), 243-252.

127. McIlvried, H. G. Kinetics of the hydrodenitrification of pyridine. Ind. Eng. Chem. Proc. Des. Dev., 1971, 10(1), 125-130.

128. Katzer, J. R., Sivasubramanian, R. Process and catalyst needs for hydrodenitrogenation. Catal. Rev., 1979, 20(2), 155-208.

129. Girgis, M. J., Gates, B. C. Reactivities, reaction networks, and kinetics in highpressure catalytic hydroprocessing. Ind. Eng. Chem. Res., 1991, 30(9), 2021-2058.

130. Benson, D. B. Catalytic hydrotreating of shale oil. [HF-activated Co molybdate was best of 12 catalysts]. Chem. Eng. Prog. (United States), 1966, 62(8), 61-67. 